\title{
Regional health inequalities in the European macrore- gion from the East Central European perspective
}

\author{
Zoltán Egri This study analyses the regional health inequalities \\ Szent István Egyetem in the European macroregion, with particular em- \\ E-mail: egri.zoltan@gk.szie.hu phasis on the mortality trends in East Central Eu- \\ rope. On one hand, our research aims focus on \\ the territorial fragmentation of the examined area, \\ the identification of main breaklines, and examina- \\ tion of mortality factors affecting differentiation. \\ On the other hand, we identify the socio- \\ economic differentiation behind regional dispari- \\ ties in health status. \\ According to our results, beyond the traditional \\ east-west division of the European macroregion, \\ additional "micro-cracks" can be detected through \\ the different variables describing health status. \\ Previously, the East Central European region was \\ somewhat unanimously disadvantaged, but now it \\ is far from being homogeneous. The main drivers \\ of regional divide are still non-communicable \\ Keywords: chronic diseases, with the main priority attached \\ regional health inequalities, \\ East Central Europe, \\ mortality crisis
}

\section{Introduction}

Nations on the eastern and western sides of the Iron Curtain - created after World War II and viewed as the political metaphor of a divided Europe - established their own socio-economic systems. The line dividing the two blocks also led to the emergence of an epidemiological (Boncz-Sebestyén 2006) (or healthcare) iron curtain (EC 2008). The spatial patterns of health status still show this persistent division between East and West (Mackenbach et al. 2013). The eastern side is characterized by a specific phenomenon (i.e. the so-called health paradox). This paradox means a strikingly high rate of premature mortality in societies under transition, this region showing a considerably worse general health status than justified on the basis of economic indicators (Cornia-Paniccia 2000, Kopp-Skrabski 2001, Kopp-Réthelyi 2004).

The features and characteristics of the health paradox can be summarized as follows. This phenomenon emerged during peacetime, over a period with no known

Regional Statistics, Vol. 7. No.1. 2017: 197-224; DOI: 10.15196/RS0711 
cases of global/regional infection, famine, or any natural disaster (Ruminska-Zimny 1997, Cornia-Paniccia 2000). While life expectancy at birth had been similar in the two blocks until the 1960s, the socialist block had been struggling with stagnation and involution from 1965 (Cornia-Paniccia 2000). Different mortality trends can be seen even within the socialist block. Prior to more recent socio-economic changes, Hungary was among the countries with the worst mortality status and trends, although Russia, the Ukraine, and the Baltic states were facing a deeper crisis (KoppSkrabski 2007). The mortality crisis mostly affected the economically active age groups, particularly men, and not the typically vulnerable groups (children or elderly people). Men were especially vulnerable to and primarily affected by excess mortality (Meslé 2001, Meslé 2004, Weidner-Cain 2003, Grigoriev et al. 2014). On the eastern side of the iron curtain, the second half of the past century saw a widening gap between life expectancy of men and women (Daróczi 2004), which continues to remain rather wide even today (Bálint 2010, Vitrai 2011).

As far as the causes of death are concerned, there are clear differences behind Europe's east-west division. The increased occurrence of cardiovascular disease in eastern countries and the beneficial impacts of the cardiovascular revolution (prevention plus innovative technologies and interventions) in western countries produced significant differences in Europe (Daróczi 2004). Additionally, the socialist region is substantially affected by mortality attributable to neoplasms (Daróczi 2004, Meslé 2004), digestive diseases, and "man-made" causes of death (Caselli et al. 2002, Ruminska-Zimny 1997, Meslé 2002, Grigoriev et al. 2014). However, the causes of excess mortality are different within the Eastern bloc: for example, at the time of the epidemiological crisis, circulatory diseases (in Poland and Bulgaria) and neoplasms and digestive diseases (in Hungary and Romania) contributed to a significant decrease in life expectancy at birth (Meslé 2004).

As summarized by Daróczi (2013) and Simonyi (2015), excess mortality may be linked to the forced processes typical of the socialist era (economic restructuring, social and political changes, emergence of informal economy, self-destructive lifestyle) and to the burden of adaptation. It should be noted that stress (as the invisible hand), as well as psychiatric and behavioural factors also play a major role in the high premature mortality rates (Kristenson et al. 1998, Cornia-Paniccia 2000, Kopp-Skrabski 2001, Kopp-Réthelyi 2004). With reference to Preston (1975) and Vagero (2010), Leon (2011) notes that the Iron Curtain also impeded the diffusion of knowledge and understanding on the prevention and treatment of non-communicable chronic diseases. In his opinion, the health status backwardness of Eastern Europe is attributable to the lack of necessary skills and strategies to deal with such diseases.

The process of socio-economic transition/transformation was also coupled with an adaptation crisis in East Central Europe and the Commonwealth of Independent

${ }^{1}$ Today it mostly refers to external death causes (e.g. murder, suicide, road accidents). Formerly, the alcoholrelated diseases also belonged to this category (mostly in the USSR) (Daróczi 2004).

Regional Statistics, Vol. 7. No.1. 2017: 197-224; DOI: 10.15196/RS0711 
States. Socio-economic changes generated a significant level of excess mortality in the region. Factors such as the abrupt and ill-managed labour market changes (job uncertainty, reduced wages, unemployment, and underemployment), impoverishment, rising inequalities, erosion of public institutions (legal order, education, healthcare) also contributed to the level of psychosocial stress (Ruminska-Zimny 1997, UNDP 1996, Kopp et al. 2007, Kopp-Skrabsi 2009, Cornia 2016). The rapid changes of socio-economic transition disturbed the 'social compass' of individuals (Csepeli et al. 2004, p. 7). There was also an increase in divorces, acts of violence (crime, murder, suicide), and migration. In each of the affected countries, mortality characteristics (gender aspect, causes of death, age group) were the same as those in the pre-transition period and were supplemented with new phenomena, such as sexually transmitted diseases and Human Immunodeficiency Virus (RuminskaZimny 1997). Male life expectancy at birth decreased by five years during 19891994 in the Russian Federation, while, in Hungary, it exceeded the 1989 level in 1996 for the first time (KSH STADAT 2016).

Caselli et al. (2002) called for a systematic approach to mortality (i.e. the theory of epidemiologic transition) (Omran 1971, Olshansky-Ault 1986) to explain the mortality crisis of the Eastern bloc, but clearly referred to this phenomenon as an exception. The region managed to surpass the era of epidemics but remained hopelessly fixed in the age of degenerative and man-made diseases. ${ }^{2}$

According to Mackenbach et al. (2013) (based on the thoughts of Rudolf Virchow) $)^{3}$, the - still present - division between East and West is attributable to the failure of various broadly defined (e.g. smoking, alcohol consumption, public road safety) health policies or healthcare systems. According to the current explanation issued by WHO (2013), health disparities between countries in the eastern and western parts of Europe are associated with two main groups of factors. These are, on one hand, differences in exposure to preventable health hazards that result from inequities in the social determinants of health, and behaviour and lifestyles (e.g. unhealthy diets, high blood pressure, dangerous or stressful working conditions, and air pollution) and, on the other hand, differences in the accessibility and quality of healthcare services.

Regarding the macro level health inequalities of the European region, the effect of path dependency is significant, which means that "decisions taken in the past largely determine the set of decisions that can be taken in the present and in the future" (Lengyel-Bajmócy 2013, p. 13). According to Simonyi (2015), the majority of social and health problems affecting East Central Europe today can be considered a heritage of the socialist era. After the regime change, the process of path creation (Simonyi 2015) already started, even if only marginally, through directly or indirectly health-related policies devised as political responses to social challenges.

2 These studies concern the period 1965-1995.

3 'Medicine is a social science, and politics is nothing more than medicine on a grand scale.' (Virchow 1848)

Regional Statistics, Vol. 7. No.1. 2017: 197-224; DOI: 10.15196/RS0711 
By using the strong presence of spatial dependency for supplementing adverse qualitative and quantitative changes in health status, Bálint (2010) assigned a spatial dimension to path dependency.

\section{Research questions and ideas}

The general objective of this study is to analyse the regional health inequalities of the European macroregion, with special regard to the processes and characteristics of East Central Europe. The following study questions and assumptions were proposed.

\section{Is there an epidemiological iron curtain or east-west division in today's regional Europe?}

Health status shows macroregional disparities between countries in the two blocks. Certain indicators (life expectancy at birth, infant mortality rate, age-standardized mortality rate etc.) provide clear visual evidence for the duality in Europe (BonczSebestyén 2006, Richardson et al. 2013, Marmot 2013, Jaworska 2014, Maynou et al. 2015). Additionally, the regional east-west division might be observed within affected countries (Kibele 2012, Marmot 2013). Nevertheless - given that regional mortality inequalities result from a combination of numerous factors - it is important to examine whether this type of differentiation also exists along with more study dimensions at regional level in Europe.

\section{Are there further breaklines in the examined European area? Do they appear at regional or national levels?}

Former studies have mostly highlighted the various differences between East and West, or examined health status disparities according to groups of countries linked by geographical, historical, political, and cultural similarities (Meslé 2001, Meslé 2004, Daróczi 2004, Avdeev et al. 2011, Sírová 2011, Mackenbach et al. 2013, WHO 2013). Factors affecting health and health inequalities display an uneven spatial distribution (CSDH 2008), and individual spatial levels show different competences. Generally, the organisation of healthcare falls into national competence, although a regional approach is applied in large countries (e.g. United Kingdom, Spain) (Mackenbach et al 2013). Furthermore, in EU member states, regional development policies are run on a community basis, while agriculture is managed under a common policy. However, the subnational level has increasing autonomy in relation to social and economic decisions, many of which relate to the social determinants of health and health inequalities (WHO 2013). As a result of these impacts, the health dimensions described in this study are characterized by a versatile spatial structure.

Regional Statistics, Vol. 7. No.1. 2017: 197-224; DOI: 10.15196/RS0711 


\section{What are the main health characteristics that determine spatial disparities?}

The typical characteristics, diseases, and groups of diseases (non-communicable chronic diseases including particularly cardiovascular diseases) of the east-west divide have already been clearly identified (Bobak-Marmot 1996, Meslé 2002, Meslé 2004, WHO 2013). Based on the cause of death approach, this paper uses mathematical/statistical methods to identify health variable(s) that enjoy(s) priority in the regional diversity of mortality. According to our hypotheses, non-communicable chronic diseases are typical determinants of the spatial structure of mortality in European regions, similarly to the disparities seen at national level.

\section{What is the extent of socio-economic differences behind the regional breaklines of health status?}

Numerous theories and models explain the socio-economic inequalities of health status (Preston 1975, DHHS 1980, Acheson 1998, Wilkinson-Marmot 2003, CSDH 2008, Mackenbach 2012, WHO 2013). Based on our literature review of regional health inequalities at the European level, few studies discuss the socio-economic inequalities of health status affecting the entire or parts of the region (e.g. the European Union) (Richardson et al 2013, Marmot 2013, Stańczyk 2015, Maynou et al. 2015). We carried out a regional analysis of the socio-economic inequalities of health status by using the main indicators of the above studies and relevant territorial policies (regional policy, Europe 2020 strategy). As a result, we assume these indicators will influence the regional division of health status, allowing us to demonstrate the main trends and relationships in the field of inequalities.

\section{Research methodology issues}

We examine regional inequalities in four steps. Accordingly, we describe our research logic, main considerations, and work methodology (territorial level, database) below.

1. Operationalization of indicators expressing/causing territorial division. Several criteria must be met to express mortality inequalities. We must use the cause of death approach, as the role of certain diseases (e.g. cardiovascular diseases malignant neoplasms, external causes) is clear in deteriorated health status and reduced life expectancy. Given that a mortality crisis affects the economically active population, we use premature mortality indicators. According to literature, men are the weaker sex in terms of mortality and male mortality must be handled as a priority category during. Health-impairing behaviour is also included among the relevant causes of death through operationalization. Although females are less affected by a mortality crisis, this dimension is also studied.

2. Creating and uploading the required database with relevant information in sufficient quantity. Prior to creating the database, we performed an literature and research

Regional Statistics, Vol. 7. No.1. 2017: 197-224; DOI: 10.15196/RS0711 
reports review to ensure the use of proper and relevant information (Meslé 2002, Daróczi 2004, Meslé-Vallin 2002, Leon 2011, Sírová 2011, Marmot 2013, WHO 2013).

3. We use three approaches for examining the territorial inequalities of health status. For technical (statistical) considerations, it is desirable to have an overall picture of each variable of territorial mortality - this way we obtain a preliminary report on regional health inequalities. Consequently, besides descriptive statistics, we applied Pearson and Spearman correlation and univariate global autocorrelation tests. Given that the various empirical sources compare groups of European countries (or individual countries representing such groups) (e.g. Meslé-Vallin 2002, Nolte et al. 2004, Leon 2011), we first describe the progress of regional health inequalities within and between country groups along pre-defined macroblocks. Second, the regions make up the elementary territorial level of the European fragmentation test, where regions with similar health status (NUTS2) are classified into homogeneous groups. Regarding methodology, we use the general linear model (Sajtos-Mitev 2007) for macroregions and - due to the numerous advantages (applicability, interpretation) - two-step cluster analysis for grouping mesoregions (Sajtos-Mitev 2007). These steps answer the first and second research questions. The created clusters are then placed on a map. While doing that and addressing the third research question, we identify the health characteristics that determine territorial disparities in the European macroregion.

4. Finally, the regional disparities of health status are compared with socioeconomic inequalities. During assessment, we describe the 'rough' socio-economic breaklines behind the mortality differences identified in our study. This answers the fourth research question/hypothesis by using discriminant and regression analysis.

\section{Delineation}

The delineation we use does not correspond to the Europe or European region defined by the WHO or that based on evident geographical or cultural considerations. Actually, our description of territorial inequalities for mortality applies to a smaller area - the European Union (28 member states) plus Norway. Therefore, any reference to the European macroregion (or Europe) in our findings refers to this area and not the larger areas mentioned in the above literature sources, that is, including the European CIS, Balkan, Mediterranean, and Caucasian countries. The reason is that a scientifically correct and reliable, as well as diverse, set of indicators is available only for this smaller area. Although in the European Union healthcare is not treated as common or community policy, the need for a supranational level for health policies and for the control of health inequalities is present - which may affect even the European Economic Area - such as policy documents, strategies, and scientific papers (EC 2007, EC 2009, WHO 2013, Richardson et al. 2013). Thus, the analysis of the macroregion can be considered relevant from a technical viewpoint and may contribute to the foundation of a community development.

Regional Statistics, Vol. 7. No.1. 2017: 197-224; DOI: 10.15196/RS0711 
NUTS2 regions are the area units for both country groups and regional analyses. The classification is based on the NUTS2013 amendment, which entered into force in 2015. The analysis excludes the overseas departments of France, autonomous regions of Portugal (Azores and Madeira), autonomous cities of Spain (Ceuta, Melilla), and the Canary Islands.

\section{Database}

When compiling the database, we tried to meet the criteria of the abovementioned research methodology. Therefore, we selected the following indicators for the study of regional health inequalities, reflecting East Central European mortality progress but also representing the issue at European level.

a) age-standardized mortality rates for 100,000 persons, males, and the 0-64 age group: diseases of the circulatory system (I00-I99), neoplasms (C00-D48), external causes of morbidity and mortality (V01-Y89), diseases of the digestive system (K00-K93);

b) infant mortality rates;

c) gender differences in life expectancy at birth.

Weighting for the age-standardized indicators is provided by the age distribution of the European standard population (Eurostat 2013). Standardization was carried out by Eurostat. The causes of death indicators were uploaded on the basis of the International Classification of Diseases (ICD) codes (10th revision) (see the ICD codes between parentheses). Due to lack of stability, the database currently offers availability only for one year (2013) - low frequency causes of death were ignored and main cause of death groups were not delineated.

The regional socio-economic inequalities of health status were examined using indicators for economic performance, labour market position, and backwardness. Economic value creation (income position, productivity) is characterized with the use of gross domestic product (GDP) per capita (EUR or purchasing power parities (PPP)), household income per capita, and productivity rate (gross regional product per workforce). Labour market involvement is shown via employment and economic activity rates (20-64 age group), unemployment rate (above 15 age group), and not by education, employment, or training (18-24 age group). The operationalized regional indicator of poverty and social exclusion is used for backwardness.

The data were obtained from the online database of Eurostat and ESPON (European Spatial Planning Observation Network) for 2012-2014. SPSS for Windows 20.0 and Geoda 1.6.7 software were used for analysis, while the figures were prepared with ArcMap 10.1.

Regional Statistics, Vol. 7. No.1. 2017: 197-224; DOI: 10.15196/RS0711 


\section{Results}

First, we describe the inequality characteristics of the first six health status indicators by the use of position and shape values, deviation and other values, and global autocorrelation tests (Table 1).

Table 1

The main indicators of health inequalities in the European macroregion

\begin{tabular}{l|c|c|c|c|c|c}
\hline & $\begin{array}{c}\text { Diseases } \\
\text { of the } \\
\text { circulatory } \\
\text { system }\end{array}$ & Neoplasms & $\begin{array}{c}\text { External } \\
\text { causes } \\
\text { of morbidity } \\
\text { and mortality }\end{array}$ & $\begin{array}{c}\text { Diseases } \\
\text { of the digestive } \\
\text { system }\end{array}$ & $\begin{array}{c}\text { Difference } \\
\text { in life expec- } \\
\text { tancy }\end{array}$ & $\begin{array}{c}\text { Infant } \\
\text { mortality }\end{array}$ \\
\hline Minimum & 27.65 & 49.07 & 12.24 & 4.00 & 3.27 & 0.00 \\
Maximum & 267.22 & 208.26 & 193.70 & 73.98 & 11.07 & 10.97 \\
Range & 239.57 & 159.19 & 181.46 & 69.98 & 7.80 & 10.97 \\
Mean & 72.49 & 93.83 & 44.77 & 21.94 & 5.42 & 3.65 \\
Median & 52.55 & 86.59 & 37.72 & 18.32 & 5.13 & 3.37 \\
Standard deviation & 49.56 & 28.72 & 22.21 & 13.45 & 1.48 & 1.52 \\
Coefficient of variation & 68.36 & 30.61 & 46.61 & 61.32 & 27.21 & 41.76 \\
Skewness & 1.98 & 1.36 & 2.22 & 1.54 & 0.75 & 2.23 \\
Kurtosis & 3.47 & 2.21 & 8.57 & 2.36 & 0.35 & 6.53 \\
Number of outliers & 42 & 10 & 8 & 19 & 2 & 18 \\
Moran's I & 0.83 & 0.80 & 0.76 & 0.79 & 0.84 & 0.70
\end{tabular}

Note: The standard error of skewness is 0.147 . Regarding Moran's I, the contiguity matrix is based on the four nearest contiguity distance matrices.

The difference between mean and median suggests what the coefficient of variation and range of individual data series clearly indicate as a high presence of territorial disparities in the analysed region. Extreme variability is shown, particularly by the causes of premature death. For skewness and kurtosis, the distribution of study indicators (except for gender differences in life expectancy at birth) cannot be considered normal, while the values for the remaining observation variable exceed the limit of +1 .

The strong positive skewness for the causes of premature death and infant mortality is a sign of marked disparities in the region. Data series symmetry cannot be assumed, given that the value of skewness is more than twice that of the standard error. The study of kurtosis shows positive and high values for the causes of premature death (including particularly diseases of the circulatory system and external causes) and infant mortality rates, which also indicates a substantial difference from the normal distribution. Applied health status indicators clarify that non-compliance with normal conditions is coupled with outliers. As our findings refer to the smaller

Regional Statistics, Vol. 7. No.1. 2017: 197-224; DOI: 10.15196/RS0711 
European region defined above, this region is not treated as a random sample but regarded as an assembly. Outliers are an integral part of this assembly, thus representing its real segmentation and supplying additional information. Therefore given that our objective is to detect inequalities - the removal or any transformation of outliers is not justified. The global autocorrelation test (Moran's I) provides information on the strong spatial dependence and regular arrangements of study indicators. This means that spatiality and contiguity are also important factors in the regional division of mortality in the macroregion.

The Pearson and Spearman coefficients were used to identify correlations between mortality indicators. Although correlations between health status indicators produce significant results, their strength provides a diverse picture (Table 2). Generally, the various causes of death tend to strengthen each other. In regions with a higher than average premature mortality rate caused by diseases of the circulatory system, high rates of premature death due to external causes, neoplasms, and diseases of the digestive system, and significant gender differences in life expectancy at birth and a rather high rate of infant mortality (and vice versa) exist. These correlations suggest that certain regions are plagued by complex backwardness in health status, while others show favourable conditions, based on the selected indicators.

Table 2

\begin{tabular}{l|c|c|c|c|c|c}
\multicolumn{6}{c}{ Correlational relationships ${ }^{4}$ of mortality variables in Europe } \\
\hline & circul & neop & ext & dig & le_diff & inf \\
\hline circul & - & $0.756^{* *}$ & $0.682^{* *}$ & $0.790^{* *}$ & $0.662^{* *}$ & $0.684^{* *}$ \\
neop & $0.552^{* *}$ & - & $0.587^{* *}$ & $0.798^{* *}$ & $0.778^{* *}$ & $0.569^{* *}$ \\
ext & $0.538^{* *}$ & $0.498^{* *}$ & - & $0.666^{* *}$ & $0.763^{* *}$ & $0.321^{* *}$ \\
dig & $0.720^{* *}$ & $0.644^{* *}$ & $0.601^{* *}$ & - & $0.646^{* *}$ & $0.584^{* *}$ \\
le_diff & $0.440^{* *}$ & $0.827^{* *}$ & $0.601^{* *}$ & $0.583^{* *}$ & - & $0.319^{* *}$ \\
inf & $0.463^{* *}$ & $0.397^{* *}$ & $0.246^{* *}$ & $0.392^{* *}$ & $0.158^{* *}$ & -
\end{tabular}

Note: See the Pearson coefficients above and Spearman (rank correlation) coefficients below the main diagonal. $* *$ means a significance level of $1 \%$.

In our opinion, the analyses performed on the structure of variables (i.e. descriptive statistics, territorial autocorrelation test, correlation analysis) provide a sufficient basis for the study of the spatial division of mortality in Europe.

${ }^{4}$ Abbreviations of mortality indicators: circul - diseases of the circulatory system, neop - neoplasms, ext external causes of morbidity and mortality, dig - diseases of the digestive system, le_diff - gender differences in life expectancy at birth, inf - infant mortality.

Regional Statistics, Vol. 7. No.1. 2017: 197-224; DOI: 10.15196/RS0711 


\section{Examination of spatial diversities by macroregion (country group)}

Several authors have already examined diversity by country group, although the European breaklines tend to be different in each source (Vallin-Meslé 2001, MesléVallin 2002, Meslé 2004, Nolte et al. 2004, Avdeev et al. 2011). Eventually, the solution applied by Vallin-Meslé (2001) comes closest to harmonizing the study area considering the various results.

Table 3

Examination areas for territorial differences by country group

\begin{tabular}{|c|c|c|}
\hline Macroregions & Vallin-Meslé (2001) grouping & Adapted grouping \\
\hline Northern Europe & $\begin{array}{c}\text { Denmark, Finland, Iceland, } \\
\text { Norway, Sweden }\end{array}$ & $\begin{array}{l}\text { Denmark, Finland, Norway, } \\
\text { Sweden }\end{array}$ \\
\hline Northwestern Europe & $\begin{array}{l}\text { Belgium, United Kingdom, } \\
\text { France, The Netherlands, } \\
\text { Ireland }\end{array}$ & $\begin{array}{l}\text { Belgium, United Kingdom, } \\
\text { France, The Netherlands, Ireland }\end{array}$ \\
\hline West Central Europe & $\begin{array}{c}\text { Austria, Luxembourg, Germa- } \\
\text { ny, Switzerland }\end{array}$ & Austria, Luxembourg, Germany \\
\hline Southern Europe & $\begin{array}{c}\text { Greece, Malta, Italy, Portugal, } \\
\text { Spain }\end{array}$ & $\begin{array}{l}\text { Greece, Malta, Italy, Portugal, } \\
\text { Spain, Cyprus }\end{array}$ \\
\hline East Central Europe $^{5}$ & $\begin{array}{c}\text { Czech Republic, Bulgaria, } \\
\text { Poland, Hungary, Romania, } \\
\text { Slovakia }\end{array}$ & $\begin{array}{c}\text { Czech Republic, Bulgaria, Poland, } \\
\text { Hungary, Romania, Slovakia, Es- } \\
\text { tonia, Latvia, Lithuania, Croatia, } \\
\text { Slovenia }\end{array}$ \\
\hline $\begin{array}{l}\text { European CIS and Baltic } \\
\text { countries }\end{array}$ & $\begin{array}{c}\text { Estonia, Belarus, Latvia, Lith- } \\
\text { uania, Moldova, Russia, } \\
\text { Ukraine }\end{array}$ & - \\
\hline Albania and former Yugoslavia & $\begin{array}{c}\text { Albania, Bosnia and Herze- } \\
\text { govina, Croatia, Yugoslavia, } \\
\text { Macedonia, Slovenia }\end{array}$ & - \\
\hline $\begin{array}{l}\text { East Mediterranean } \\
\text { and Caucasian countries }\end{array}$ & $\begin{array}{c}\text { Azerbaijan, Cyprus, Georgia, } \\
\text { Armenia and Turkey }\end{array}$ & - \\
\hline
\end{tabular}

Source: Author's elaboration based on Vallin-Meslé (2001) and Daróczi (2004).

In view of the examination area, the European CIS and Baltic countries, Albania and the former Yugoslavia, and the East Mediterranean and Caucasian countries are underrepresented at regional level. Therefore, we moved these countries to other macroregions (Table 3). Particularly, due to their socialist heritage and "new" EU member state status, the Baltic countries, Croatia, and Slovenia were moved to East Central Europe. Due to its geographical location and similarly good health status, Cyprus was reclassified as a Southern European country.

5 The original paper (Vallin-Meslé 2001) uses the term 'Central Europe'. However, in line with the arguments made by János Rechnitzer (2013) (about the former political establishment, geopolitical situation etc.), the term 'East Central Europe' is thought to be more accurate.

Regional Statistics, Vol. 7. No.1. 2017: 197-224; DOI: 10.15196/RS0711 
The differences between country groups were identified using GLM (general linear model). This method is a combination of traditional variance and linear regression analyses (Sajtos-Mitev 2007). The dependent variables are the mortality indicators described above, while the fixed (independent) variable is the numeric variable assigned to individual country groups. The number of regions in the various macroregions is different ${ }^{6}$ and, according to the results of Levene's test, the variances within groups are not the same in the case of observable variables. In addition to one-way ANOVA (analysis of variance), we have used the Games-Howell posthoc test, designed for the comparison of medians. This latter test is not sensitive to equal variance and sample size criteria (Shingala-Rajyaguru 2015). The results are shown in Table 4, where the means, number of significant differences between means, and partial eta-squared values explain the division for groups of countries that belong together for geographical, historical, political, and cultural reasons.

Table 4

Mortality breaklines by country group

\begin{tabular}{l|c|c|c|c|c|c}
\hline & $\begin{array}{c}\text { Northern } \\
\text { Europe }\end{array}$ & $\begin{array}{c}\text { Northwestern } \\
\text { Europe }\end{array}$ & $\begin{array}{c}\text { West Central } \\
\text { Europe }\end{array}$ & $\begin{array}{c}\text { Southern } \\
\text { Europe }\end{array}$ & $\begin{array}{c}\text { East Central } \\
\text { Europe }\end{array}$ & $\begin{array}{c}\text { Partial } \\
\text { eta-squared }\end{array}$ \\
\hline circul & $48.65^{(2)}$ & $47.37^{(2)}$ & $58.55^{(3)}$ & $51.27^{(1)}$ & $155.73^{(4)}$ & 0.737 \\
neop & $62.45^{(4)}$ & $84.37^{(2)}$ & $84.97^{(2)}$ & $88.56^{(2)}$ & $135.49^{(4)}$ & 0.602 \\
ext & $45.89^{(3)}$ & $40.62^{(3)}$ & $33.34^{(3)}$ & $30.55^{(3)}$ & $74.97^{(4)}$ & 0.525 \\
dig & $15.08^{(1)}$ & $17.45^{(3)}$ & $20.76^{(3)}$ & $13.19^{(3)}$ & $41.89^{(4)}$ & 0.602 \\
le_diff & $4.28^{(3)}$ & $4.69^{(2)}$ & $4.98^{(3)}$ & $5.44^{(4)}$ & $7.43^{(4)}$ & 0.528 \\
inf & $2.59^{(3)}$ & $3.65^{(4)}$ & $3.17^{(3)}$ & $2.97^{(2)}$ & $5.21^{(4)}$ & 0.320
\end{tabular}

Note: the significant average differences are shown in parentheses for the relevant country group.

In view of ANOVA, the individual group means differ significantly from each other, giving a solid basis for the spatial division between country blocks in health status. The extent of territorial differences, according to partial eta-squared values, varies for individual variables. The difference between blocks is lowest for infant mortality $(0.320)$ and highest for premature circulatory mortality (0.737). Consequently, the unfavourable position of East Central Europe confirms the existence of an east-west spatial division between country groups. The means for East Central Europe are rather unfavourable in comparison with (and always significantly different from) those of other territorial units. We have also performed a comparison using the indicator of relative mortality risk ${ }^{7}$ (Sándor 2004, Ádány 2011) from mor-

\footnotetext{
${ }^{6}$ Number of regions in Northern Europe: 25, North-Western Europe: 87, West Central Europe: 48, Southern Europe: 57, and East Central Europe: 56.

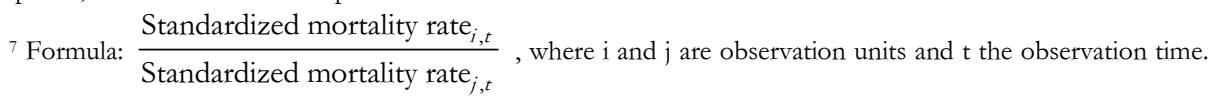
Observation unit $\mathrm{j}$ is considered the reference region.
}

Regional Statistics, Vol. 7. No.1. 2017: 197-224; DOI: 10.15196/RS0711 
tality literature. First, the individual indicators of East Central Europe are compared with those of the country group having the second worst mortality. Second, the means of the country groups showing the second and third worst mortality variables are compared using the relative mortality risk (Table 5).

Table 5

Values of the relative mortality risk in the examined area

\begin{tabular}{l|c|c}
\hline \multirow{2}{*}{} & \multicolumn{2}{|c}{ The relative mortality risk of } \\
\cline { 2 - 3 } & East Central Europe & The second worst value \\
\hline circul & 2.66 & 1.14 \\
neop & 1.53 & 1.04 \\
ext & 1.63 & 1.13 \\
dig & 2.02 & 1.19 \\
inf & 1.43 & 1.15
\end{tabular}

Note: For East Central Europe, the reference is the country group having the second worst value, which is then compared with the country group showing the third worst value.

The results provide information on the extent of the east-west division. Mortality inequalities are substantial: for example, the probability of men dying prematurely from diseases of the circulatory system in East Central Europe is 2.66 higher than in West Central Europe. Regarding other variables in East Central Europe, the relative mortality risk also shows great diversity, mostly when the country groups registering the second and third worst values are compared.

We also examined the impact of each country group on Europe's territorial division in view of the selected health indicators. For this purpose, we used the tables of regression parameter estimates of the general linear model (Table 6).

Table 6

Regression parameter estimation of the general linear model (circulatory mortality)

\begin{tabular}{l|r|r|c|c}
\hline \multicolumn{1}{c|}{ Parameters } & \multicolumn{1}{c|}{ Beta } & $\mathrm{t}$ & Sig. & Partial eta-squared \\
\hline Constant & 155.73 & 45.45 & 0.000 & 0.885 \\
Northern Europe & -107.08 & -17.37 & 0.000 & 0.530 \\
Northwestern Europe & -108.36 & -24.69 & 0.000 & 0.695 \\
West Central Europe & -97.17 & -19.28 & 0.000 & 0.581 \\
Southern Europe & -104.46 & -21.67 & 0.000 & 0.637
\end{tabular}

The constant in the regression equation indicates the means of the highest value category (here, East Central Europe), which is identified as omitted or reference group in literature (UCLA 2007, Taylor 2011). This serves as a benchmark for calculating the individual group means with the help of the beta coefficients of territorial

Regional Statistics, Vol. 7. No.1. 2017: 197-224; DOI: 10.15196/RS0711 
units. ${ }^{8}$ Of course, the regression relationships confirm the circulatory mortality values in Table 4, based on - for each regression coefficient - t-statistic values, significance levels, and partial eta-squared values. In this particular case, the t-values highlight the role played by individual country groups in influencing territorial inequalities. Apart from the reference group (East Central Europe), North-Western Europe has a rather high effect on the spatial distribution of the circulatory mortality in the examined area (Table 6).

Table 7

Partial eta-squared values of country groups by GLM regression

\begin{tabular}{l|c|c|c|c|c}
\hline & $\begin{array}{c}\text { Northern } \\
\text { Europe }\end{array}$ & $\begin{array}{c}\text { Northwestern } \\
\text { Europe }\end{array}$ & $\begin{array}{c}\text { West Central } \\
\text { Europe }\end{array}$ & $\begin{array}{c}\text { Southern } \\
\text { Europe }\end{array}$ & $\begin{array}{c}\text { East Central } \\
\text { Europe }\end{array}$ \\
\hline circul & 0.530 & 0.695 & 0.581 & 0.637 & 0.885 \\
neop & 0.508 & 0.499 & 0.425 & 0.410 & 0.920 \\
ext & 0.187 & 0.387 & 0.413 & 0.466 & 0.832 \\
dig & 0.388 & 0.510 & 0.371 & 0.543 & 0.834 \\
le_diff & 0.379 & 0.476 & 0.354 & 0.285 & 0.917 \\
inf & 0.217 & 0.163 & 0.201 & 0.249 & 0.780
\end{tabular}

Supplementary, the partial eta-squared values, present in the regression equation of each variable, are shown by country group (Table 7). As evidenced by our calculations, apart from East Central Europe, Southern Europe and North-Western Europe have a major impact on the spatial structure of health inequalities in terms of the relevant health variables. The former is an important player in the field of external causes, infant mortality and diseases of the digestive system, while the latter is a major actor in circulatory diseases and differences in life expectancy. The spatial structure of health inequalities is influenced only to a lesser extent by Northern Europe in infant mortality and premature deaths from neoplasms, and by West Central Europe in external causes of death.

\section{Mesoregional examination of spatial diversity}

The purpose of the mesoregional approach to analysing mortality is to identify the main boundaries of spatial division and classify into homogeneous groups the individual NUTS2 regions showing similar mortality characteristics. For this purpose, we used the algorithm of two-step cluster analysis.

As per Table 2, the pairs do not show too close (above 0.9) correlations, which means there is no excessive redundancy or distortion in the database. However, overall information (common variance) on the group of variables is missing. As such, the

\footnotetext{
${ }^{8}$ As a special feature, each group is defined as a dummy variable. For example, when estimating the average circulatory mortality in Northern Europe, this macroregion will take the value 1 and the others 0 . Accordingly, the equation is $y=155.73-1 * 107.08-0 * 108.36-0 * 97.17-0 * 104.46$ (i.e. the value for Northern Europe will be 48.65 ).
}

Regional Statistics, Vol. 7. No.1. 2017: 197-224; DOI: 10.15196/RS0711 
index expressing the adequacy of indicators applied for main component analysis is applied (Table 8). According to the Kaiser-Meyer-Olkin index, redundancy is present among the applied indicators, but only to a moderate extent (Füstös 2009).

Based on the previous results (descriptive statistics, global territorial autocorrelation test, macroregion approach) and correlation relationships, at regional level, there is a clear spatial separation along the examined vectors.

Table 8

\begin{tabular}{l|l|c}
\multicolumn{2}{c}{ Redundancy test for mortality variables } \\
\hline Kaiser-Meyer-Olkin Measure of Sampling Adequancy & 0.789 \\
\hline \multirow{3}{*}{ Bartlett's test of Sphericity } & Approx. Chi-Square & 1367.33 \\
& df & 15 \\
& Sig. & 0.000
\end{tabular}

The variables were entered in standardized form into the algorithm of the twostep cluster analysis, which was then run separately for both distance measures (Euclidean and $\log$-likelihood). We opted for the latter measure to ensure a proper technical interpretation of the results. As the method is designed to provide automatic proposals for the optimal number of clusters (Sajtos-Mitev 2007), we first selected this automatic clustering option, and - to identify additional breaklines we defined the number of clusters. We used the BIC (Schwarz's Bayesian information criterion) applicable to various cluster arrangements (number of clusters), BIC change, and the ratio of changes and distance measures (Trpkova-Tevdovski 2009) to express the quality of homogeneous groups. The created clusters were checked with one-way ANOVA and, where possible (for three or more groups), the Games-Howell post-hoc test was again used for comparing means.

The obtained results were also evaluated in terms of which variables contribute and to what extent - to cluster formation. Ranging between 0 and 1 , the index of predictor importance was evaluated with the F-test. The closer the index to 1, the less likely the separation between clusters is due to chance and more likely due to the impact of a variable (IBM 2012).

The two homogeneous clusters, created with the automatic clustering option, display a marked east-west difference (Figure 1). The coverage for the region with unfavourable health characteristics (Cluster 2) indicates the problem continues to be an issue in East Central Europe.

Table 9

Average mortality gap in the divided European macroregion ( 2 clusters)

\begin{tabular}{l|r|r|r|c|c|c}
\hline & circul & neop & ext & dig & le_diff & inf \\
\hline Cluster 1 & 51.93 & 83.11 & 37.25 & 16.92 & 4.93 & 3.21 \\
Cluster 2 & 164.20 & 141.65 & 78.27 & 44.32 & 7.65 & 5.61 \\
Average (examined area) & 72.50 & 93.83 & 44.77 & 21.94 & 5.42 & 3.65
\end{tabular}

Note the ANOVA results highlight the significant difference between cluster means.

Regional Statistics, Vol. 7. No.1. 2017: 197-224; DOI: 10.15196/RS0711 
In addition to Estonia, Latvia, Lithuania, Poland, Slovakia, Hungary, Romania, and Bulgaria, geographically contiguous blocks free from contiguity relations are formed by Continental Croatia and the eastern areas mostly affected in the industrial transformation of the Czech Republic (Stredni Morava, Moravskoslezsko). The high mortality regions joining from a shorter and greater distance (Severozápad [Cz], Nord-Pas-de-Calais [Fr]) show partly similar socio-economic characteristics (industrial reconstruction leading to unfavourable results, OECD 2004, Ministry of Employment and Solidarity High Committee of Public Health 2002, Laoudj Chekraoui 2014).

Figure 1

\section{Spatial differentiation of the European macroregion in the case of two clusters}

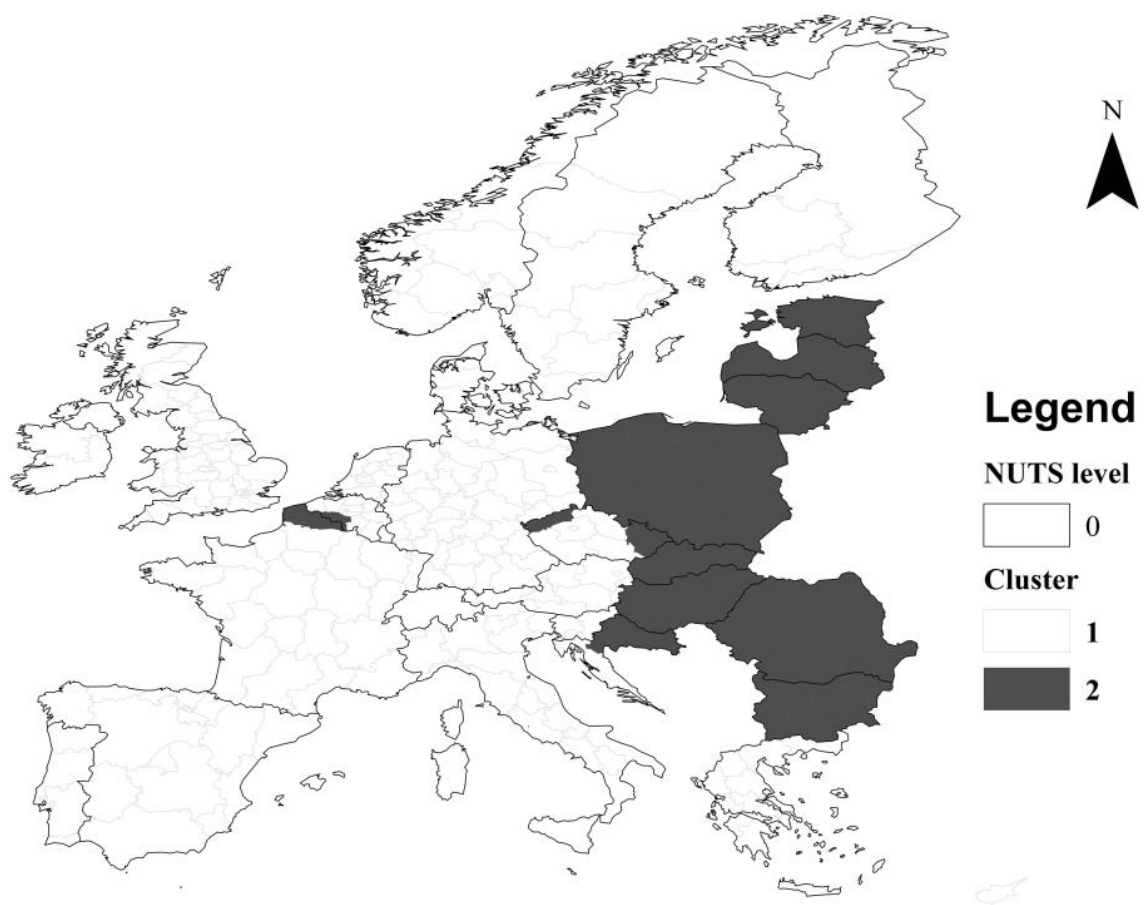

Note: BIC: 676.6; BIC change: -523.0; ratio of change: 1.0; ratio of distance measure: 5.8. Switzerland is not included in the analysis.

According to Renard et al. (2015), the high number of deaths and the mortality profile (similar to that of East Central Europe) of Hainaut province (Belgium), neighbouring the region of Northern France, are explained by the long-term economic segregation of the Walloon region and the failure of regional public policies. The framework of this study excludes from the clusters such areas, formerly showing as interim features, such as Eastern and Western Slovenia, Adriatic Croatia, the central part of the Czech Republic, or the East German (former GDR) provinces.

Regional Statistics, Vol. 7. No.1. 2017: 197-224; DOI: 10.15196/RS0711 
Based on the comparative European analyses of Meslé $(2002,2004)$ and MesléVallin (2002), in 1995, the countries in these regions belonged to the relatively more developed areas of the eastern part of Europe regarding health status. There is a significant difference between the two blocks in terms of all mortality indicators (Table 9). The eastern part of the examined area displays the following relative risks for premature causes of death (in comparison with Cluster 1): diseases of the circulatory system -3.16 ; neoplasms -1.70 ; external causes of morbidity and mortality 2.10; diseases of the digestive system -2.60 . Gender differences in life expectancy at birth are 2.7 years higher in Cluster 2, and infant mortality is $74 \%$ higher than in the reference region.

Examining only the major part of Czech Republic from the more developed cluster, its favourable position can be explained by several factors. According to a joint study by Caselli, Meslé, and Vallin (2002), the transformation crisis affecting health status was fairly short in the Czech Republic, and the country's life expectancy at birth began increasing in 1991. As a positive example, Cornia (2016) mentions the rigorous reform steps taken by the Czech Republic during socio-economic transition, thus demonstrating a realistic pace of restructuring and strong labour, social sector, and redistributive policies (WHO 2013, Simonyi 2015). According to an explanation provided by Mackenbach et al. (2013), the Czech Republic is performing better in terms of health status than many other countries in East Central Europe due to its efficient overall health policies, including teenage pregnancies and neonatal mortality, cancer screening and road traffic safety. Rychtarikova (2004) and Mackenbach et al. (2013) highlight the improvement of health status is likely to be attributable to the rapid results of the cardiovascular revolution and the technical progress in the treatment of cardiovascular diseases (surgeries, innovative medicines), thus being less affected by health awareness (alcohol consumption, smoking).

Subsequently, to identify additional breaklines, we defined three and then four clusters. The three-cluster solution continues to confirm the East Central European origin of poor mortality statuses (Figure 2). There is no major rearrangement in the region when Central Moravia (Stredni Morava) or Nord-Pas-de-Calais and Hainaut and moved to the newly formed group with interim mortality indicators (Table 10, Cluster 2).

Table 10

\begin{tabular}{l|r|r|c|c|c|c}
\multicolumn{7}{c}{ Mortality features in the European macroregion (3 clusters) } \\
\hline & circul & neop & ext & dig & le_diff & inf \\
\hline Cluster 1 & 49.96 & 75.58 & 32.49 & 14.92 & 4.32 & 3.42 \\
Cluster 2 & 56.42 & 97.58 & 46.48 & 21.03 & 6.05 & 2.85 \\
Cluster 3 & 169.45 & 142.73 & 79.08 & 44.89 & 7.69 & 5.75 \\
Average (examined area) & 72.50 & 93.83 & 44.77 & 21.94 & 5.42 & 3.65
\end{tabular}

Note: cluster means (in general) show a difference on the basis of ANOVA results, while there is a significant difference between each of the three clusters according to the post-hoc test.

Regional Statistics, Vol. 7. No.1. 2017: 197-224; DOI: 10.15196/RS0711 
This lies along the cluster of least favourable characteristics (Cluster 1), and consists of regions adjacent to it. The other large part of the group is located in Western Europe (Portugal, Spain, France etc.). Cluster 2, showing an average performance for most vectors, is mostly organized in correspondence with current (Finland, Slovenia, France, Portugal, and the majors part of Spain and Czech Republic) or former (GDR) country borders. However, in other cases (e.g. Belgium, Austria, Croatia, Greece) there are signs of regional fragmentation within a given country. The examined European region shows a mortality slope in line with the order of cluster numbering. The only discrepancy is observed in infant mortality, with Cluster 2 outperforming Cluster 1.

Figure 2

\section{Regional differences in the European macroregion by certain mortality indicators} (three clusters)

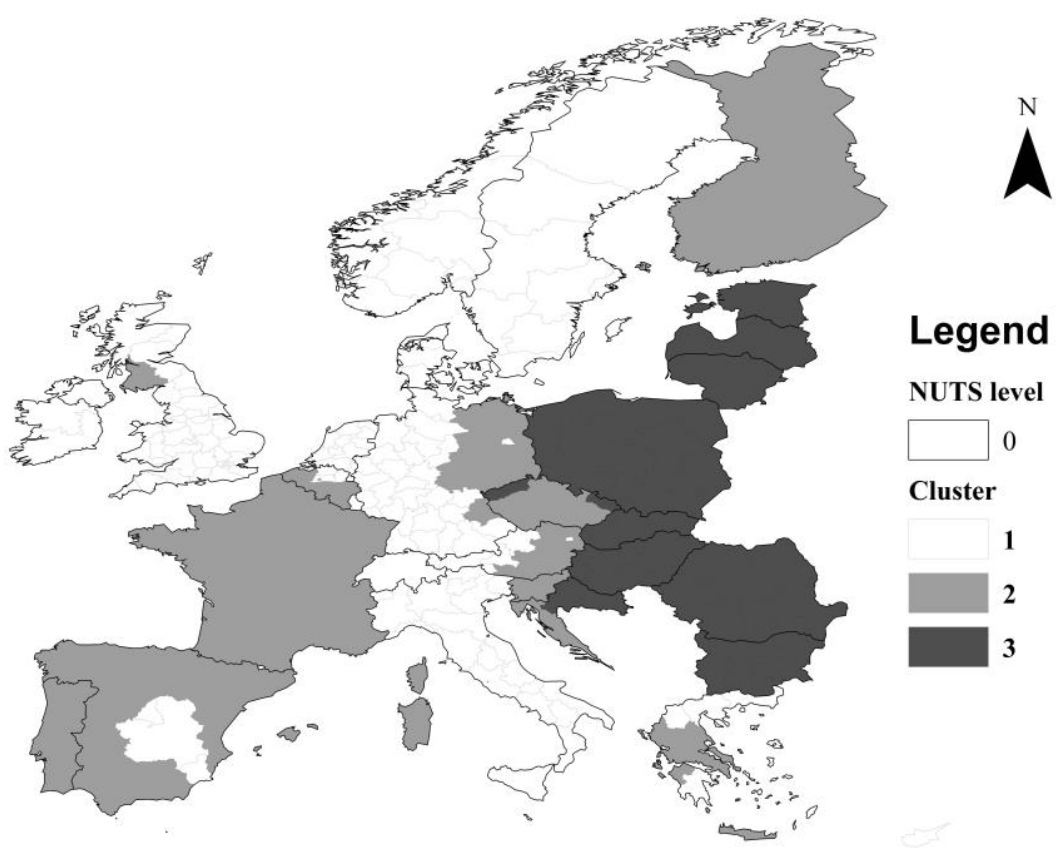

Note: BIC: 641.9; BIC change: -34,7; ratio of change: 0.066; ratio of distance measure: 1.6. Switzerland is not included in the analysis.

When four clusters are defined, some rearrangements can be observed within the individual groups (Figure 3). The East Central European region is affected most by the movements causing a northern-southern split of the cluster, with the worst features hitherto detected. North, the Baltic countries, Poland, central and western NUTS2 regions of Slovakia (Stredné Slovensko, Západné Slovensko, Bratislava), and peripheral regions of the Czech Republic merge with Central Hungary and Continental Croatia into the same cluster. Nord Pas-de-Calais is also part of this group.

Regional Statistics, Vol. 7. No.1. 2017: 197-224; DOI: 10.15196/RS0711 
South, Bulgaria and Romania, as well as Hungary, except for its central region, and Eastern Slovakia form a single block. For observable variables, mostly the southern cluster (Cluster 4) shows unfavourable properties (Table 11). However, the detached northern group displays significant excess mortality rates - due to external causes of premature death and gender differences in life expectancy at birth - both for southern areas and average values. Except for these two phenomena, the mortality slope is still present in the analysed area.

Table 11

\section{Regional disparities in the European macroregion in case of 4 clusters}

\begin{tabular}{l|r|r|c|c|c|c}
\hline & circul & neop & ext & dig & le_diff & inf \\
\hline Cluster 1 & 49.96 & 75.58 & 32.49 & 14.92 & 4.32 & 3.42 \\
Cluster 2 & 55.70 & 96.83 & 46.05 & 20.64 & 6.02 & 2.85 \\
Cluster 3 & 144.71 & 129.78 & 88.31 & 38.88 & 8.03 & 4.14 \\
Cluster 4 & 194.44 & 158.57 & 65.34 & 52.12 & 7.19 & 7.64 \\
Average (examined area) & 72.50 & 93.83 & 44.77 & 21.94 & 5.42 & 3.65
\end{tabular}

Note: Cluster means (in general) show a difference on the basis of ANOVA results, while there is a significant difference between each of the four clusters according to the post-hoc test.

Main breaklines of the analysed area by the four-cluster solution

Figure 3

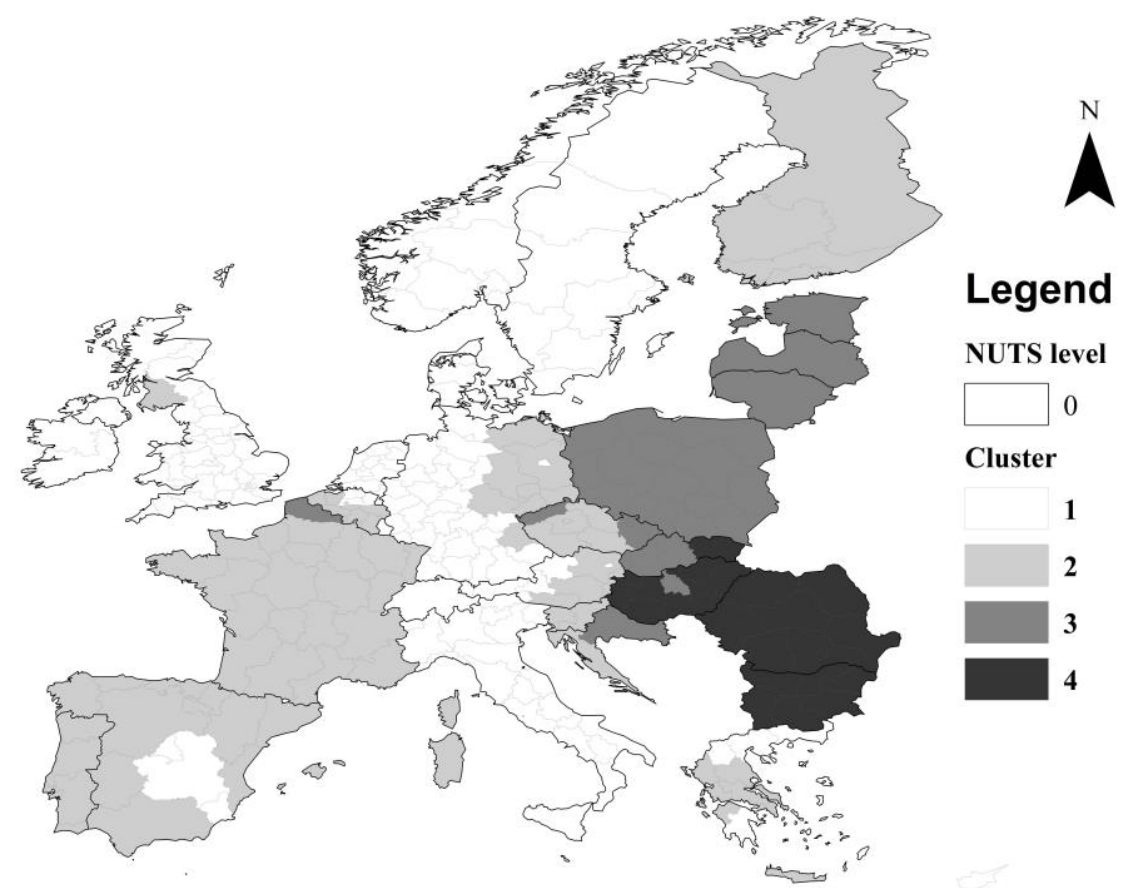

Note. BIC: 624.5; BIC change: 3.2; ratio of change: -0.06 ; ratio of distance measure: 2.0. Switzerland is not included in the analysis.

Regional Statistics, Vol. 7. No.1. 2017: 197-224; DOI: 10.15196/RS0711 
The importance of cluster forming variables (Table 12) highlights the extent of disparities caused in the relevant European area by the health status indicators involved in this study. Within this evaluation framework, premature cardiovascular mortality represents the main determinant of regional health inequalities for each cluster solution. Subsequently, gender differences in life expectancy at birth generate a considerable level of regional fragmentation, followed by premature neoplasms, diseases of the digestive system, external causes, and, finally, infant mortality. In line with our hypothesis, the priority of non-communicable chronic diseases, particularly including cardiovascular diseases, is also valid under the mesoregional approach.

Table 12

Impact of factors on the territorial inequalities of the European macroregion

\begin{tabular}{l|c|c|c|c|c|c}
\hline Cluster solution & circul & le_diff & neop & dig & ext & inf \\
\hline 2 & 1.0 & 0.49 & 0.67 & 0.67 & 0.49 & 0.33 \\
3 & 1.0 & 0.87 & 0.78 & 0.64 & 0.53 & 0.34 \\
4 & 1.0 & 0.84 & 0.83 & 0.67 & 0.55 & 0.57
\end{tabular}

\section{Socio-economic differentiation of reqional health inequalities in the European macroregion}

Here, we identify the factors affecting the described health inequalities and determine the socio-economic indicators that make the previously defined mortality clusters differ among them. Instead of building complex explanatory models, our study is limited to highlighting the main trends and relationships of spatial inequalities.

Table 13

Socio-economic inequalities of health inequalities in the European macroregion

\begin{tabular}{l|c|c}
\hline \multicolumn{1}{c|}{ Nr. of Clusters } & Productivity & GDP per capita \\
\hline 1. & 11.07 & 10.30 \\
& $(66.760)$ & $(31.369)$ \\
2. & 10.99 & 10.11 \\
& $(61.189)$ & $(25.325)$ \\
3. & 10.67 & 9.82 \\
& $(44.720)$ & $(19.329)$ \\
4. & 10.34 & 9.48 \\
& $(32.604)$ & $(13.952)$ \\
Box's M sig. & 0.558 & 0.152 \\
Wilks' Lambda & 0.585 & 0.607 \\
F & 63.63 & 58.12 \\
Sig. & 0.000 & 0.000
\end{tabular}

Note: the upper part contains the average logarithmised economic performance values of each cluster (PPP units in parentheses), while the lower part shows the main results of discriminant analysis.

Regional Statistics, Vol. 7. No.1. 2017: 197-224; DOI: 10.15196/RS0711 
First, we applied discriminant analysis for this purpose - a method suitable for determining a linear combination of independent variables that are 'best' at discriminating the relevant predefined groups (for clusters) (Sajtos-Mitev 2007).

The analysis is based on the four-cluster solution for the mortality examination. The method requirements (measurement level of variables, mutually exclusive groups, group size, normality, homogeneity of variance) are fulfilled by two independent variables. The logarithmized values of the productivity rate and GDP per capita - expressing economic value creation and calculated at PPP - indicate parallel inequalities corresponding to the mortality slope. These correlations confirm the main findings of relevant literature sources (Marmot 2013, Richardson et al. 2013), according to which indicators of economic value can explain regional health inequalities for large-scale area units (e.g. EU or a part of it).

The independent variables have a significant impact, but this influence is considered weak/moderate for the purpose of discriminating the groups. Accordingly, there is a relationship similar to that of a Preston curve (Preston 1975, 2007): higher economic performance is coupled with better health status.

Supplementary, we show the regional Preston curve to bring a somewhat new perspective to the relationship between these two phenomena (Figure 4). The dependent variable of regression is life expectancy at birth, while the independent variable is GDP per capita at PPP. According to the logarithmic function best fitting the data series, economic performance accounts for $35.4 \%$ of health status heterogeneity. The corresponding regression equation is:

Life expectancy at birth $=3.7698 \ln ($ GDP per capita $)+42.635$.

This regression function shows a variation significantly higher than justified on the basis of national results (Preston 1975, WHO 2008, Orosz-Kollányi 2016). The study of Orosz and Kollányi (2016) defines the regression curve as an 'expected' health status in relation to economic performance, and examines the location of individual area units in the function. The units below the curve underperform as a result of factors other than economic performance (e.g. economic efficiency, social characteristics, healthcare), while the situation is the opposite for units located above the regression curve.

Contrary to the previous socio-economic examination of health inequalities, the different marking on Figure 4 assigns not to the clusters created, but to the regions of the analysed area (East Central Europe). As per Figure 4, the cross-sectional relationship between GDP per capita and life expectancy produced two distinct patterns: $93 \%$ of East Central European regions 'underperform', with the exception of four regions: Eastern and Western Slovenia (Vzhodna Slovenija, Zahodna Slovenija), Adriatic Croatia (Jadranska Hrvatska), and the Polish Sub-Carpathians (Podkarpackie). Figure 4 highlights the capital regions, while Table 14 shows GDP per capita amounts and lists the differences between actual and estimated (through the regression equation) 'expected' life expectancy values.

Regional Statistics, Vol. 7. No.1. 2017: 197-224; DOI: 10.15196/RS0711 
Preston curve at regional level

Figure 4

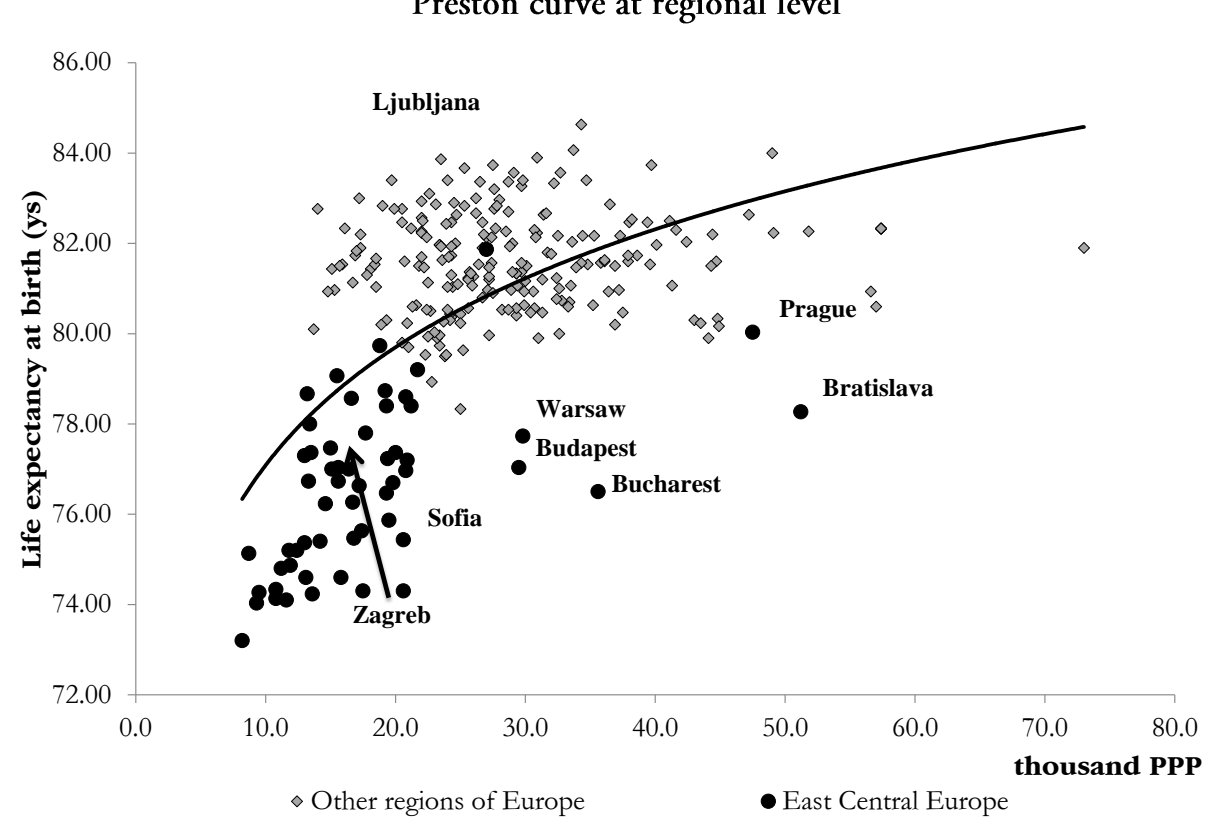

Note: The capital regions of East Central Europe are listed.

Table 14

Relationship of the GDP per capita and the "expected" health condition in the capital regions of East Central Europe

\begin{tabular}{l|c|c}
\hline \multicolumn{1}{c|}{ Region } & $\begin{array}{c}\text { GDP per capita } \\
\text { (\% of EU average at PPP })\end{array}$ & Difference in life expectancy \\
\hline Bratislava & 184 & -4.98 \\
Prague & 173 & -2.93 \\
Budapest & 108 & -4.13 \\
Warsaw & 107 & -3.47 \\
Bucharest & 131 & -5.37 \\
Ljubljana & 97 & +1.04 \\
Sofia & 72 & -4.38 \\
Zagreb & 62 & -1.95
\end{tabular}

Note: Difference in life expectancy lists the differences between actual and estimated (through regression equation described above) “expected” life expectancy values.

Accordingly, despite the economic performance of most regions above the EU average, significant lags can be observed in terms of life expectancy at birth. The Bratislava region, with the highest GDP per person values, is lagging some five years behind the expected level, similar to the Romanian and Central Hungarian

Regional Statistics, Vol. 7. No.1. 2017: 197-224; DOI: 10.15196/RS0711 
regions. The highest value is registered by Western Slovenia (including Ljubljana), but Prague is also in a relatively better position. Based on national (population weighted) averages, Slovenia exceeds the expected health status (+0.62 years), followed by Croatia ( -1.20 years) and the Czech Republic ( -1.60 years). Lithuania ( $-5,51$ years), Latvia ( -4.90 years), and Romania ( -3.47 years) are at the bottom of the list. Hungary ( -3.40 years) is slightly above Romania, but below Bulgaria $(-3.11$ years). This means that, under the study conditions, the health paradox exists at regional level as well.

Roughly expressing socio-economic inequalities in health status, both our examinations are suitable only for the detection of general trends and relationships. We did not take into consideration numerous explanatory or country-specific factors (policies, eating habits, lifestyles etc.). As to ill-managed policies on alcohol-related issues, Mackenbach et al. (2013) refer to the example of Finland, which stands second on the mortality slope and does not belong to the group of best performing region in our mesoregional analysis of health inequalities (Figure 2 and 3). When neighbouring Estonia joined the European Union, Finland dramatically and continuously reduced its alcohol tax to compensate for the much lower price of alcoholic beverages in Estonia. At the same time, alcohol-related mortality rates were constantly on the rise prior to the tax increase.

The importance of path dependency, that is, the (naturally) unavoidable impact of the socialist era's heritage needs to be emphasized although not included in the subject of this study or as an explanatory factor in either the discriminant or regression analyses. Nevertheless, the regional distribution of mortality clearly shows the effects of historical heritage (Figures 1-4). Actually, the socio-economic and other impact factors of today's health status (social problems, lifestyles etc.) are typically influenced by the processes and consequences of the socialist era (Simonyi 2015).

\section{Summary}

Our study analyses regional health inequalities in the European macroregion, with emphasis on the mortality trends in East Central Europe. On one hand, our research questions focus on the territorial fragmentation of the examined area, identification of the main breaklines, and examination of mortality factors affecting the differentiation. On the other hand, our study identifies the socio-economic differentiation behind the regional disparities of health status.

As evidenced by our examinations of country groups and also by the mesoregional approach, the excess mortality in the examined area is still a burden of East Central Europe. In view of the abovementioned features (major role of noncommunicable chronic diseases, involvement of men, vulnerability of economically active age group), this problem causes a marked breakline in the analysed European area. Beyond the traditional east-west division of the European macroregion, additional 'micro-cracks' can be detected through the different vectors describing health

Regional Statistics, Vol. 7. No.1. 2017: 197-224; DOI: 10.15196/RS0711 
status. Clusters are mostly organized along former and current country borders. In our opinion, these findings reflect the complex impacts of various national regulatory systems, society, politics, economy, and culture.

Our study clarifies that the East Central European region, which used to be homogeneously disadvantaged, is far from being homogeneous today. The western block of areas that enjoyed a relatively better health status at the time of the regime change (e.g. East Germany, Czech Republic) and the western region of Slovenia and Croatia are surpassing the contiguous East Central European block. The regions on the eastern side of the Iron Curtain continue their differentiation along the northern-southern direction, displaying somewhat better indicators in the North than the South.

The methods used do not consider - or consider to a small extent - spatial impacts and contiguity relations. Nevertheless, the indicators reveal the importance of these phenomena in the formation of mortality clusters. As far as the subject of this study is concerned, Europe shows contiguous clusters and centre/periphery zones.

The main drivers of the regional divide are still non-communicable chronic diseases, with cardiovascular diseases taking absolute precedence. According to a report on future trends (Bloom et al. 2011), the most vulnerable countries in terms of economic loss attributable to non-communicable diseases are those classified in the high-income and upper-middle-income groups (e.g. countries in East Central Europe). The global loss generated by cardiovascular diseases and cancer mortality until will amount USD 24 billion by 2030, representing 38\% of global GDP of 2010 , of which USD 21 billion ( $88 \%$ of total) will be the loss of countries in the said income groups (own calculation by Bloom et al. 2011). Although individual income groups show significant variations in terms of income and population, given the unfavourable demographic and public health situations in East Central Europe, this region will most probably register above-average losses during the period mentioned above.

According to our results of applying a mesoregional approach to identify the socio-economic differentiation behind the regional disparities in health status for the delineated European macroregion, a parallel economic performance (GDP, productivity) gradient can be observed besides the mortality slope. This is refined with further analysis, performed at the NUTS2 level, to obtain a Preston curve, which confirms the health paradox exists at the regional level as well. In other words, most regions in East Central Europe fail to reach an expected health status in view of their economic performance.

Although our study ignored the effects of country-specific and impact factors (e.g. national policies affecting health status) or socialist heritage, literature findings (Mackenbach et al. 2013, Simonyi 2015) highlight the importance of these factors. Therefore, socialist heritage must be handled as an unavoidable background variable in further studies on this topic.

Regional Statistics, Vol. 7. No.1. 2017: 197-224; DOI: 10.15196/RS0711 


\section{Acknowledgement}

Supported by the ÚNKP-16-4 New National Excellence Program of the Ministry of Human Capacities.

\section{REFERENCES}

ACHESON, D. (1998): Independent inquiry into inequalities in health report The Stationary Office, London.

BÁLINT, L. (2010): A területi halandósági különbségek Magyarországon 1980-2006 KSH Népességtudományi Kutató Intézet, Budapest.

Bloom, D. E.-CAfiero, E. T.-Jané-Llopis, E.-Abrahams-Gessel, S.-Bloom, L. R.FAthima, S.-Feigl, A. B.-Gaziano, T.-MOWAFI, M.-PANDyA, A.-PRETTtNer, K.-Rosenberg, L.-Seligman, B.-Stein, A. Z.-Weinstein, C. (2011): The Global Economic Burden of Noncommunicable Diseases World Economic Forum, Geneva.

BOBAK, M.-MARMOT, M. (1996): East-West mortality divide and its potential explanations: proposed research agenda British Medical Journal 312 (7028):421-425.

BONCZ, I.-SEBESTYÉN, A. (2006): Economy and mortality in Eastern and Western Europe between 1945 and 1990: the largest medical trial of history International Journal of Epidemiology 35 (3): 796-797.

CAselli, G.-Meslé, F.-VAllin, J. (2002): Epidemiologic transition theory exceptions Genus 58 (1): 9-52.

COMMISSION ON SOCIAL DETERMINANTS OF HEALTH (CSDH) (2008): Closing the gap in a generation: health equity through action on the social determinants of health. Final Report of the Commission on Social Determinants of Health World Health Organization, Geneva.

Cornia, G. A.-PAniCCIA, R. (2000): The Transition Mortality Crisis: Evidence, Interpretation and Policy Responses Oxford University Press, New York.

Csepeli, Gy.-ÖrkÉNY, A.-SzÉKelYI, M.-BARNA, I. (2004): Bizalom és gyanakvás Szociálpszichológiai akadályok a piacgazdasághoz vezető úton Szociológiai Szemle 11 (1): 3-35.

DARÓCZI, E. (2003): A középkorúak halandósága nemek és főbb halálokok szerint Az epidemiológiai átmenet sajátosságai Magyarországon In Daróczi, E. (eds.): Kettốs szoritásban A középgenerációk élete és egészsége pp. 105-124., KSH-NKI, Budapest.

DARÓCZI, E. (2004): Európa kelet-nyugati megosztottsága az életesélyek terén In: DARÓczI, E.-KovÁcs, K. (eds.): Halálozási viszonyok az ezredfordulón: társadalmi és földrajzi választóvonalak pp.11-40., KSH-NKI, Budapest.

Department of Health AND Human Services (DHHS) (1980): Inequalities in health: report of a research working group (The Black Report) HMSO, London.

EUROSTAT (2013): Revision of the European Standard Population Report of Eurostat's task force Publications Office of the European Union, Luxembourg.

Regional Statistics, Vol. 7. No.1. 2017: 197-224; DOI: 10.15196/RS0711 
FÜSTÖS, L. (2009): A sokváltozós adatelemzés módszerei In: FÜSTÖS L.-SZALMA, I. (eds.): Módszertani füzetek 2009/1 MTA Szociológiai Kutatóintézete Társadalomtudományi Elemzések Akadémiai Mühelye (TEAM), Budapest.

Grigoriev, P.-Meslé, F.-Shkolnikov, V. M.-Andreev, E.-Fihel, A.-PeChHOLdova, M.-VAluin, M. (2014): The Recent Mortality Decline in Russia: Beginning of the Cardiovascular Revolution? Population and Development Review 40 (1): 107-129.

JAwOrskA, R. (2014): Health Inequalities Across The European Union Regions: A BetaConvergence Approach Comparative Economic Research 17 (4): 71-86.

Kibele, E. U. B. (2012): Regional Mortality Differences in Germany Springer Science+Business Media, Dordrecht.

KOPP, M.-RÉTHELYI, J. (2004): Where psychology meets physiology: chronic stress and premature mortality- the Central-Eastern European health paradox Brain Research Bulletin 62 (5): 351-367.

Kopp, M.-SKRABSKI, Á. (2009): Nők és férfiak egészségi állapota Magyarországon In: NAgY, I.-PONGRÁCZ, T.-NÉ (eds.): Szerepváltozások. Jelentés a nōk és férfiak helyzetéról 2009 pp. 117-136., TÁRKI - Szociális és Munkaügyi Minisztérium, Budapest.

Kopp, M.-Skrabski, Á.-SzÉKEly, A.-Williams, R. (2007): Chronic stress and social changes, socioeconomic determination of chronic stress Annals of the New York Academy of Sciences 1113 (1): 325-338.

KOPP, M.-SKRABSKI, Á. (2007): A magyar népesség életkilátásai Magyar Tudomány 168 (9): 1149-1153.

Kristenson，M.-Kucinskiene，Z.-Bergdahl，B.-CAlKauskas，H.-Urmonas，V.ORTH-GOMER, K. (1998): Increased psychosocial strain in Lithuanian versus Swedish men: the LiVicordiastudy Psychosomatic Medicine 60 (3): 277-282.

LAOUdJ CHEKRAOUI, F. (2014): Spatial differences of mortality: social and medical factors South East European Journal of Political Science (SEEJPS) 2 (3): 31-41.

LENGYEL, B.-BAJMÓCY, Z. (2013): Regionális és helyi gazdaságfejlesztés az evolúciós gazdaságföldrajz szemszögéből Tér és Társadalom 27 (1): 5-29.

LEON, D. A. (2011): Trends in European life expectancy: a salutary view International Journal of Epidemiology 40 (2): 271-277.

MACKENBACH, J. (2012): The persistence of health inequalities in modern welfare states: The explanation of a paradox Social Science \& Medicine 75 (4): 761-769.

Mackenbach, J. P.-Karanikolos, M.-MCKeE, M. (2013): The unequal health of Europeans: successes and failures of policies Lancet 381: 1125-1134.

MARmot, M. (2013): Health inequalities in the EU - Final report of a consortium European Commission Directorate-General for Health and Consumers, Brussels.

MAYNOU, L.-SAEZ, M.-BACARIA, J.-LOPEZ-CASASNOVAS, G. (2015): Health inequalities in the European Union: an empirical analysis of the dynamics of regional differences The European Journal of Health Economics 16 (5): 543-559.

Meslé, F.-VAllin, J. (2002): Mortality in Europe: the Divergence Between East and West Population 57 (1): 157-197.

MeSLÉ, F. (2001): Halandóság Kelet- és Nyugat-Európában: növekvő különbségek Regio: Kisebbség, Politika, Társadalom 12 (1): 163-176.

Regional Statistics, Vol. 7. No.1. 2017: 197-224; DOI: 10.15196/RS0711 
Olshansky, S. J.-Ault, B. (1986) The Fourth Stage of the Epidemiologic Transition: The Age of Delayed Degenerative Diseases The Milbank Quarterly 64 (3): 355-391.

Omran, A. (1971): The Epidemiologic Transition A Theory of the Epidemiology of Population Change The Milbank Memorial Fund Quarterly 49 (4): 509-538.

OROSZ, É.-KOLLÁNYI, Zs. (2016): Egészségi állapot, egészség-egyenlőtlenségek nemzetközi összehasonlításban In: KOLOSI, T.-TÓTH, I. GY. (eds.): Társadalmi Riport pp. 334-357., TÁRKI, Budapest.

PRESTON, S. H. (1975, 2007): The changing relation between mortality and level of economic development. Reprinted International Journal of Epidemiology (2007) 36 (3): 484-490.

RECHNITZER, J. (2013): Adalékok Kelet-Közép-Európa térszerkezetének felrajzolásához Közép-Európai Közlemények 6 (1-2): 238-250.

Richardson, E. A.-PeArCe, J.-Mitcheld, R.-ShorTt, N. K.-Tunstall, H. (2013): Have regional inequalities in life expectancy widened within the European Union between 1991 and 2008? European Journal of Public Health 24 (3): 357-363.

RYCHTAŘ́íKOVÁ, J. (2004): The case of the Czech Republic: Determinants of the recent favorable turnover in mortality Demographic Research Special Collection (2): $105-138$.

SAjTOS L.-MiTEV, A. (2007): SPSS kutatási és adatelemzési kézikönyv Alinea Kiadó, Budapest.

SÁNDOR, J. (2004): Mortalitás In: BAKACS, M.-Vitray, J. (eds.): Népegészségügyi jelentés pp. 1-67., Országos Epidemiológiai Központ, Budapest.

Shingala, M. C.-RAjyaguru, A. (2015): Comparison of Post Hoc Tests for Unequal Variance International Journal of New Technologies in Science and Engineering 2 (5): 22-33.

ŠírOVÁ, S. (2011): The development of cardiovascular mortality in selected European countries $A U_{c}$ Geographica 46 (1): 53-69.

STAŃCZYK, R. (2015): Convergence of Health Status in the European Union: A Spatial Econometric Approach ATINER'S Conference Paper Series, No: PUH20151586, Athens.

Trpkova, M.-Tevdovski, D. (2009): Twostep cluster analysis: Segmentation of largest companies in Macedonia In: KovÁcs, P.-SzÉP, K.-KATONA, T. (eds.): Challenges for Analysis of the Economy, the Businesses, and Social Progress pp. 302-320., Universitas Szeged Press, Szeged.

VAGERO, D. (2010): The East-West health divide in Europe: growing and shifting Eastwards European Review 18 (1): 23-34.

VAldin, J.-Meslé, F. (2001): Trends in mortality in Europe since 1950: age-, sex- and causespecific mortality In: VAllin, J.-Meslé, F.-VALKOnEN, T. (eds.): Trend in mortality and differential mortality pp. 31-184., Council of Europe, Brussels.

ViTRAI, J. (2011): Az egészség és az egészségegyenlótlenség egyéni és közösségi befolyásoló tényezôi Doktori értekezés Pécsi Tudományegyetem Egészségtudományi Kar, Egészségtudományi Doktori Iskola.

WeIDneR, G.-CAIN, V. (2003): The Gender Gap in Heart Disease: Lessons from Eastern Europe American Journal of Public Health 93 (5): 768-770.

Regional Statistics, Vol. 7. No.1. 2017: 197-224; DOI: 10.15196/RS0711 
WHO (2008): The World Health Report. Primary Health Care Now. More than ever WHO Press, Geneva.

WHO (2013): Review of social determinants and the health divide in the WHO European Region: final report WHO Regional Office for Europe, Copenhagen.

Wilkinson, R.-MARMOT, M. (2003): Social determinants of health: the solid facts WHO Press, Copenhagen.

\section{INTERNET REFERENCES}

Avdeev, A.-Eremenko, T.-Festy, P.-Gaymu, J.-Le Bouteillec, N.-Springer, S. (2011): Populations and Demographic Trends of European Countries, 19802010 Population 66 (1): 9-133. http://www.cairn-int.info/abstract-E_ POPU_1101_0009--populations-and-demographic-trends-of-eu.htm (downloaded: 01.10 .2016$)$

CORNIA, G. A. (2016): The mortality crisis in transition economies IZA World of Labor, Institute for the Study of Labor. http://wol.iza.org/articles/mortality-crisis-intransition-economies-1.pdf (downloaded: 23.07.2016)

EC (2009): Szolidaritás az egészségügyben: Az egészség terén mutatkozó egyenlótlenségek csökkentése az Európai Unióban http://ec.europe.eu/health/ph_determinants /socio_economics/documents/com2009_hu.pdf (downloaded: 22.10.2015)

EUROPEAN COMMISSION (2007): White Paper Together for Health: A Strategic Approach for the EU 2008-2013 http://ec.europa.eu/health/ph_overview/ Documents/strategy_wp_en.pdf (downloaded: 22.10.2015)

EUROPEAN COMMUNITIES (2008): Egészségügyi vasfüggöny Európában? Sajtóközlemény. http://www.europarl.europa.eu/sides/getDoc.do?language=hu\&type $=$ IM-PRESS\&reference $=20081009$ IPR39072 (downloaded: 19.08.2011)

EUROSTAT online database http://ec.europa.eu/eurostat/data/database (downloaded: 20.09.2016)

ESPON online database http://database.espon.eu/db2/ (downloaded: 20.09.2016)

IBM (2012): IBM SPSS Modeler 15 Algorithms Guide IBM Corporation. $\mathrm{ftp}$ // public.dhe.ibm.com/software/analytics/spss/documentation/modeler/15. 0/en/AlgorithmsGuide.pdf (downloaded: 12.07.2016)

Kopp, M.-SkrabSKI, Á. (2001): Pszichoszociális tényezók és egészségi állapot A Népesedéspolitikai ad-hoc Munkabizottság számára készített tanulmány. demografia.hu/kiadvanyokonline/index.php/demografia/article/download/200/326 (downloaded: 20.10.2014)

KSH STADAT online database. http://www.ksh.hu/docs/hun/xstadat/xstadat_hosszu/ h_wdsd001b.html (downloaded: 07.12.2016)

MESLÉ, F. (2002): Mortality in Eastern Europe and the former Soviet Union : longterm trends and recent upturns IUSSP/MPIDR Workshop "Determinants of Diverging Trends in Mortality." http://citeseerx.ist.psu.edu/viewdoc/download? doi=10.1.1.565.6610\&rep= rep1\&type=pdf (downloaded: 12.11 .2015$)$

MesLÉ, F. (2004): Mortality in Central and Eastern Europe: long-term trends and recent upturns Demographic Research Special Collection 2. http:/ /www.demographicresearch.org/special/2/3/s2-3.pdf (downloaded: 20.10.2014)

Regional Statistics, Vol. 7. No.1. 2017: 197-224; DOI: 10.15196/RS0711 
Ministry of Employment and Solidarity High COMmitTe on Public Health (2003): Health in France John Libbey Eurotext, Paris. www.hcsp.fr /Explore.cgi/Telecharger?NomFichier=hc001521.pdf (downloaded: 23.10.2015)

Nolte, E.-MCKeE, M.-Gilmore, A. (2004): Morbidity and mortality in transition countries in the European context Background paper for the thematic session "Morbidity, mortality and reproductive health: Facing challenges in transition countries" at the European Population Forum 2004., UK http://citeseerx.ist.psu.edu / viewdoc/download?doi=10.1.1.133.7041\&rep=rep1\&type $=$ pdf $\quad$ (downloaded: 10.09.2016)

OECD (2004): OECD Territorial Reviews: Czech Republic 2004 OECD Publishing, Paris. http://www.keepeek.com/Digital-Asset-Management/oecd/urban-rural-andregional-development/oecd-territorial-reviews-czech-republic2004_9789264106413-en\#page1 (downloaded: 23.10.2015)

RENARD, F.-TAFFOREAU, J.-DEBOOSERE, P. (2015): Mapping the cause-specific premature mortality reveals large between-districts disparity in Belgium, 2003-2009 Archives of Public Health 73 (13): 1-18. https://www.ncbi.nlm.nih.gov /pmc/articles/PMC4412101/pdf/13690_2015_Article_60.pdf (downloaded: 18.08.2016)

Ruminska-Zimny, E. (1997): Human Poverty in Transition Economies: Regional Overview for HDR 1997. http://hdr.undp.org/en/reports/global/hdr1997/papers/ ewa_ruminska.pdf (downloaded: 02.03.2011)

SCIENCE QUOTES BY RUdOLF VIRCHOW https://todayinsci.com/V/Virchow_ Rudolf/VirchowRudolf-Quotations.htm (downloaded: 18.08.2016)

SimonyI, A. (2015): Synthesis Report: Social Cohesion and Social Policies GrowthInnovation-Competitiveness Fostering Cohesion in Central and Eastern Europe. Grinkoh Working Papers, Series 5. http://www.grincoh.eu/media/syhtnesis _reports/grincoh_wp5_synthesis_report_simonyi.pdf (downloaded: 21.02.2016)

TAYlor, A. (2011): Using the GLM Procedure in SPSS www.psy.mq.edu.au /psystat/documents/GLMSPSS.pdf (downloaded: 22.10.2015)

UCLA Statistical Consulting Group (2007): Introduction to SPSS http://www.ats.ucla.edu /stat/spss/faq/dummy.htm (downloaded: 24.03.2016)

UNDP (1996): Human Development Report 1996. Economic Growth and Human Development http://hdr.undp.org/sites/default/files/reports/257/hdr_1996_en_ complete_nostats.pdf (downloaded: 24.12.2010)

Regional Statistics, Vol. 7. No.1. 2017: 197-224; DOI: 10.15196/RS0711 